\title{
EFFECTS OF PHYSICAL TRAINING ON THE MYOCARDIUM OF FEMALE LDL KNOCKOUT OVARIECTOMIZED MICE
}

\author{
EFEITOS DO TREINAMENTO FÍSICO SOBRE O MIOCÁRDIO DE CAMUNDONGOS LDL KNOCKOUT \\ FÊMEAS OVARIECTOMIZADAS
}

Original Article

ARTIGO ORIGINAL

Artículo Original

\author{
EFECTOS DEL ENTRENAMIENTO FÍSICO SOBRE EL MIOCARDIO DE RATONES LDL KNOCKOUT \\ HEMBRAS OVARIECTOMIZADAS
}

\begin{abstract}
Ledimar Brianezi ${ }^{1,2}$
(Physical Education Professional)

Mara Rubia Marques ${ }^{3}$

(Dentist)

Clever Gomes Cardoso 3

(Biomédic)

Maria Luiza de Jesus Miranda (Physical Education Professional)

Fernando Luiz Affonso Fonseca, 4 (Pharmacist-Biochemist)

Laura Beatriz Mesiano Maifrino 1,6 (Biomedic and e Dental Surgeon)

1. Universidade São Judas Tadeu, Programa de Pós-Graduação, São Paulo, SP, Brazil.

2. Faculdade Adventista de Hortolândia (UNASP), Campus Hortolândia, Hortolândia, SP, Brazil. 3. Universidade Federal de Goiás (UFG), Departamento de Histologia, Embriologia e Biologia Molecular, Goiania, GO, Brazil.

4. Faculdade de Medicina do ABC (FMABC), Laboratório de Análises Clínicas, Santo André, SP, Brazil. 5. Universidade Federal de São Paulo (UNIFESP), Departamento de Ciências Biológicas, Diadema, SP, Brazil.

6. Instituto Dante Pazzanese de Cardiologia, São Paulo, SP, Brazil.
\end{abstract}

\section{Correspondência:}

Rua Pastor Hugo Gegembauer, 265, Parque Hortolândia, Hortolândia, São Paulo, SP, Brasil. 13184-010. ledimar.brianezi@ucb.org.br; ledimarbr@hotmail.com

\begin{abstract}
Introduction: The emergence of coronary heart disease increases with menopause, physical inactivity and with dyslipidemia. It is known that physical training promotes the improvement of cardiovascular functions. Objective: The purpose of this study was to investigate the effects of aerobic physical training on the left ventricle in female LDL knockout ovariectomized mice. Methods: Thirty animals were divided into 6 groups $(n=5)$, namely, sedentary non-ovariectomized control; sedentary ovariectomized control; trained ovariectomized control; sedentary non-ovariectomized; sedentary ovariectomized; and trained ovariectomized. We analyzed the mean nuclear volume parameters, the cross sectional area of the myocytes, the apparent density of the capillaries, interstitium, myocytes and collagen fibers. Results: The results show that for the density of the number of nuclei, the physical activity decreased to values close to the ovariectomized control group. Regarding the mean nuclear volume and the average area of myocytes, training and ovariectomy promoted the elevation of these values but hypercholesterolemia was lower. the volume density of myocytes, hypercholesterolemia showed an increase of these values as well as the training. There was no change in the volumetric density of the capillaries and the density of collagen fibers. The training caused the decrease in the density of the interstitial volume, and the hypercholesterolemia changed to a smaller one than the control group. Conclusion: We concluded that the moderate aerobic activity or the training time used in our study were not sufficient to generate significant alterations in the hypercholesterolemic group.
\end{abstract}

Keywords: heart ventricles; exercise; menopause.

\section{RESUMO}

Introdução: O surgimento da doença cardíaca coronariana aumenta com menopausa, inatividade física e dislipidemia. Sabe-se que o treinamento físico promove a melhora das funçôes cardiovasculares. Objetivo: O objetivo deste estudo foi investigar os efeitos do treinamento físico aeróbico sobre o ventrículo esquerdo em camundongos $L D L$ knockout fêmeas ovariectomizadas. Métodos: Trinta animais foram divididos em 6 grupos $(n=5)$, a saber, controle sedentário não ovariectomizado, controle sedentário ovariectomizado, controle treinado ovariectomizado, sedentário não ovariectomizado, sedentário ovariectomizado e treinado ovariectomizado. Analisamos os parâmetros médios do volume nuclear, a área transversal dos miócitos, a densidade aparente dos capilares, interstício, miócitos e fibras colágenas. Resultados: Os resultados mostram que, para a densidade do número de núcleos, a atividade física diminuiu para valores próximos ao grupo controle ovariectomizado. Quanto ao volume nuclear médio e à área média de miócitos, treinamento e ovariectomia promoveram a elevação desses valores, mas hipercolesterolemia foi menor. A densidade de volume de miócitos, a hipercolesterolemia tiveram aumento desses valores, bem como o treinamento. Não houve mudança da densidade volumétrica dos capilares e da densidade das fibras de colágeno. O treinamento causou a diminuição da densidade do volume intersticial, e a hipercolesterolemia mudou para menor que a do grupo controle. Conclusão: Concluímos que a atividade aeróbica moderada ou o tempo de treinamento usado em nosso estudo não foram suficientes para gerar alterações significantes no grupo hipercolesterolêmico.

Descritores: ventrículos do coração; exercício; menopausa.

\section{RESUMEN}

Introducción: El surgimiento de la enfermedad cardíaca coronaria aumenta con la menopausia, la inactividad física y la dislipidemia. Se sabe que el entrenamiento físico promueve la mejora de las funciones cardiovasculares. Objetivo: El objetivo de este estudio fue investigar los efectos del entrenamiento físico aeróbico sobre el ventrículo izquierdo en ratones LDL knockout hembras ovariectomizadas. Métodos: Treinta animales fueron divididos en 6 grupos $(n=5)$, a saber, control sedentario no ovariectomizado; control sedentario ovariectomizado; control entrenado ovariectomizado; sedentario no ovariectomizado; sedentario ovariectomizado y entrenado ovariectomizado. Se analizaron los parámetros medios del volumen nuclear, el área transversal de los miocitos, la densidad aparente de los capilares, el intersticio, los miocitos y las fibras colágenas. Resultados: Los resultados muestran que, para la densidad del número de núcleos, la actividad disminuyó a valores cercanos al grupo control ovariectomizado. Con relación al volumen 
nuclear promedio y al área promedio de los miocitos, entrenamiento y ovariectomía promovieron la elevación de esos valores, pero la hipercolesterolemia fue menor. La densidad de volumen de los miocitos, la hipercolesterolemia tuvieron aumento de esos valores, así como el entrenamiento. No hubo cambio de la densidad volumétrica de los capilares y la densidad de las fibras de colágeno. El entrenamiento causó la disminución de la densidad del volumen intersticial y la hipercolesterolemia cambió para menor que la del grupo control. Conclusión: Concluimos que la actividad aeróbica moderada o el tiempo de entrenamiento utilizado en nuestro estudio no fueron suficientes para generar cambios significativos en el grupo hipercolesterolémico.

Descriptores: ventrículos cardíacos; ejercicio; menopausia.

\section{INTRODUCTION}

During the aging process, women experience a decrease in estrogen, featuring menopause, favoring the development of risk factors such as dyslipidemia, hypertension, insulin resistance, changes in the composition and distribution of fat and sedentary lifestyle associated with higher prevalence development of cardiovascular disease (CD) 1,2.

The aging process is accompanied by increased oxidative stress, i.e., increased production of reactive oxygen species (ROS), resulting in damage of various cellular macromolecules, partly due to a decrease in antioxidant capacity as well as in its lesser ability to repair resulting in increased susceptibility to apoptosis ${ }^{3,4}$. Particularly in women in the menopausal stage, neuroendocrine changes affect the functionality, metabolic capacity and the antioxidant activity of various organs, especially due to lack of estrogen, considered a female antioxidant resulting in a further increase in oxidative stress ${ }^{5}$.

The lipid metabolism is also influenced by physiological changes in menopause, resulting in increased LDL and decreased HDL and contributes to the development of cardiovascular diseases ${ }^{6,7}$. When compared with men of the same age, postmenopausal women have an increased risk of developing heart disease ${ }^{8,9}$. It is a major cause of morbidity and mortality at this physiological stage. ${ }^{10}$

Regular physical activity alleviates the effects of aging and menopause and improved aerobic fitness, maintaining body weight index of visceral fat, plasma levels of lipids, increased insulin sensitivity increase baroreflex sensitivity and improving endothelial function, increasing shear stress on the capillary walls by increasing blood flow by stimulating nitric oxide release ${ }^{11-13}$. These factors promote better quality of life related to health and prolonging survival and can be considered as a non-pharmacological standards essential in the treatment of postmenopausal effects and other physiological and pathological conditions ${ }^{14,15}$.

This study aims to verify the effects of moderate aerobic exercise training on left ventricular (LV) cholesterol knockout female mice submitted to ovarian hormone deprivation.

\section{MATERIALS AND METHODS}

Were used 30 female mice, with 10 months of age, 15 wild animals C57BL / 6J and LDL-15 Knockout animals, obtained from the Central Animal Facility of the University of São Paulo. The animals were kept in a vivarium of USJT in temperature $\left(22-24^{\circ} \mathrm{C}\right)$ and controlled illumination (12 hours cycle of day and 12 hours night) received commercial feed (NUVILAB CR1, Nuvital Nutrients LTDA, Curitiba, PR) and water "ad libitum". The experimental protocol was approved by the Ethical Committee in Research of the Universidade São Judas Tadeu (CEP-Protocol: 058/2007), and this investigation was Conducted in Accordance with the Principles of Laboratory Animal Care Formulated by the National Institutes of Health.

The animals were divided into 6 groups $(n=5)$ : non-ovariectomized sedentary control (CS), sedentary ovariectomized control (COS); trained ovariectomized control (TOC); LDL-Knockout not sedentary ovariectomized (LDL-S), LDL-Knockout ovariectomized sedentary (LDL-OS) and LDL-Knockout ovariectomized trained (LDL-OT).

At nine months of age, the rats underwent ovariectomy procedure. The effectiveness of the procedure was determined by observation of vaginal smear for secretion by light microscopy.

\section{Training protocol}

All animals underwent an adjustment period (7 days / 10 min) on treadmill. After this period, the TOC groups and LDL-OT began training protocol moderate intensity, with speed and phase load (1 hour per day, 5 days a week, with 50 to $60 \%$ of maximum effort speed, for 4 weeks). All animals underwent the maximal exercise test ${ }^{9}$.

\section{Processing of samples}

At the end of training, the animals were sacrificed by decapitation. Thoracotomy was performed in which the heart was removed, washed with brine, the atria were removed and separate the right ventricle of the left ventricle. The left ventricle was fixed in 10\% formaldehyde solution for 24 hours, dehydrated in increasing alcohol series, diaphanized with xylene, embedded in paraffin and sectioned in $6 \mathrm{~mm}$ thick and examined under a light microsc ope cuts. The sections were stained by hematoxylin-eosin and picrosirius methods.

\section{Histomorphometric analysis}

Twenty photomicrographs were captured by animal with increase of x100 and x400, totaling 100 frames per group and transferred to an image analysis software (Axio Vision, Zeiss) and Image J. The following parameters were analyzed: number density of nuclei (Nv [nu]) and Nuclear Medium Volume (V); the cross-sectional area of myocytes (AST). To obtain the mean nuclear volume $(V)$ was used the formula $V=a 2$ $\mathrm{x} b / \mathrm{a}=1.91$ where $\mathrm{a}=$ the smallest diameter of the core, $\mathrm{B}=$ greater core diameter and 1.91 is a constant.

Through stereological analysis, using the test system with a total of 204 points, corresponding to 100\% of the image, were analyzed volume densities of the capillary ( $\mathrm{V} v$ [cap]), the interstitium ( $\mathrm{V} v$ [int]), myocytes ( $\mathrm{V} v$ [myo]) and collagen fibers ( $\mathrm{Vv}[\mathrm{cf}]$ ), and the amounts are expressed in percentages. The results were presented as mean and standard error.

The analysis of variance (ANOVA) two way, and post-hoc Tukey have been duly applied for data analysis. The significance level for all tests was set at $p<0.05$.

The 7200 ApopTag ${ }^{\circledR}$ Peroxidase in situ kit (Millipore, Germany) was used according to manufacturer's instructions. TdT enzyme, in exception, was used in a ratio of $15 \%$ diluted in $85 \%$ of reaction buffer.

The numbers of apoptotic ventricular cells were assessed manually by one operator (C.G.C.) who was blinded to the different groups. A light microscope coupled to a digital camera (Zeiss, Germany) was used to obtain the images and the photomicrographs were scanned with the AxioVision software (Zeiss, Germany). For the quantification of apoptotic cells 30 images for each experimental group were captured ( $n=3$ animals/ group; 400x magnification). Results were expressed as media of the relative frequency (\%) of apoptotic cells in relation to the total number of cells. 


\section{RESULTS}

The results showed that ovariectomy, animals from control groups (COS), promoted a significant increase in cross section area parameters (AST) (+ 66\%), medium nuclear volume (V) (+1\%), interstitial volume density $(\mathrm{V} v$ [int]) (+46\%) and decrease in volume density of myocytes ( Vv [mio]) (-8\%) when compared to sedentary control group (CS). We observed that the exercise (COT), promoted significant increases in AST (+64\%), V (+88\%), Nv [nu] (+21\%), Vv [int] (+350\%), Vv [cap] (+305\%), Vv [myo] (+10\%) and decreased $\mathrm{Vv}$ [cf] (-31\%) compared to the sedentary control group (COS) (Figures 1, 2 and 3).

As for dyslipidemic animals (LDL-S) we found a significant increase in $\mathrm{Nv}$ [nu] (+64\%), Vv [myo] (+4\%) and decrease in Vv [int] (-40\%) compared with the group CS. Ovariectomy (LDL-OS) induced a significant increase in Nv [nu] (+14\%), AST (+33\%) and V (+37\%) when compared to the LDL-S group. Exercise (LDL-OT) promoted increased AST (+10\%), $\mathrm{V}(+21 \%), \mathrm{Vv}$ [mio] $(+2 \%)$ and decrease in $\mathrm{Vv}$ [int] (-20\%) and Nv [nu] (-32\%) compared to LDL-OS group (Figures 1, 2 and 3).

By Tunel assay it was found that ovariectomy increased the rate of apoptosis in the control groups (COS) and the physical training was not able to restore this rate (COT). In sedentary dyslipidemic animals and ovariectomized (LDL-S and LDL-OS) cell death increased considerably compared to the control groups, however, physical training (LDL-OT) reduced cell death to levels close to the sedentary control group (CS) (Figure 1).

\section{DISCUSSION}

In this study, ovariectomized and / or hypercholesterolemic mice were subjected to physical training and morphometric variables of the left cardiac ventricle were evaluated in order to investigate the effect of exercise training on the heart of postmenopausal females individuals. Several trials using biochemical and physiological parameters in ovariectomized females, have shown that physical activity has beneficial effects for both cardiac tissue and other body tissues. In ascending aortic dyslipidemic ovariectomized female mice, subjected to physical training, was evidenced lower percentage of visceral adipose tissue and decreased blood pressure as well as quantitative changes in the volume densities of elastic lamellae and collagen fibers ${ }^{16}$. In women with low levels of estrogen, physical activity resulted in reduction in blood pressure and improvements in myocardial activity and cardiac function ${ }^{17}$.

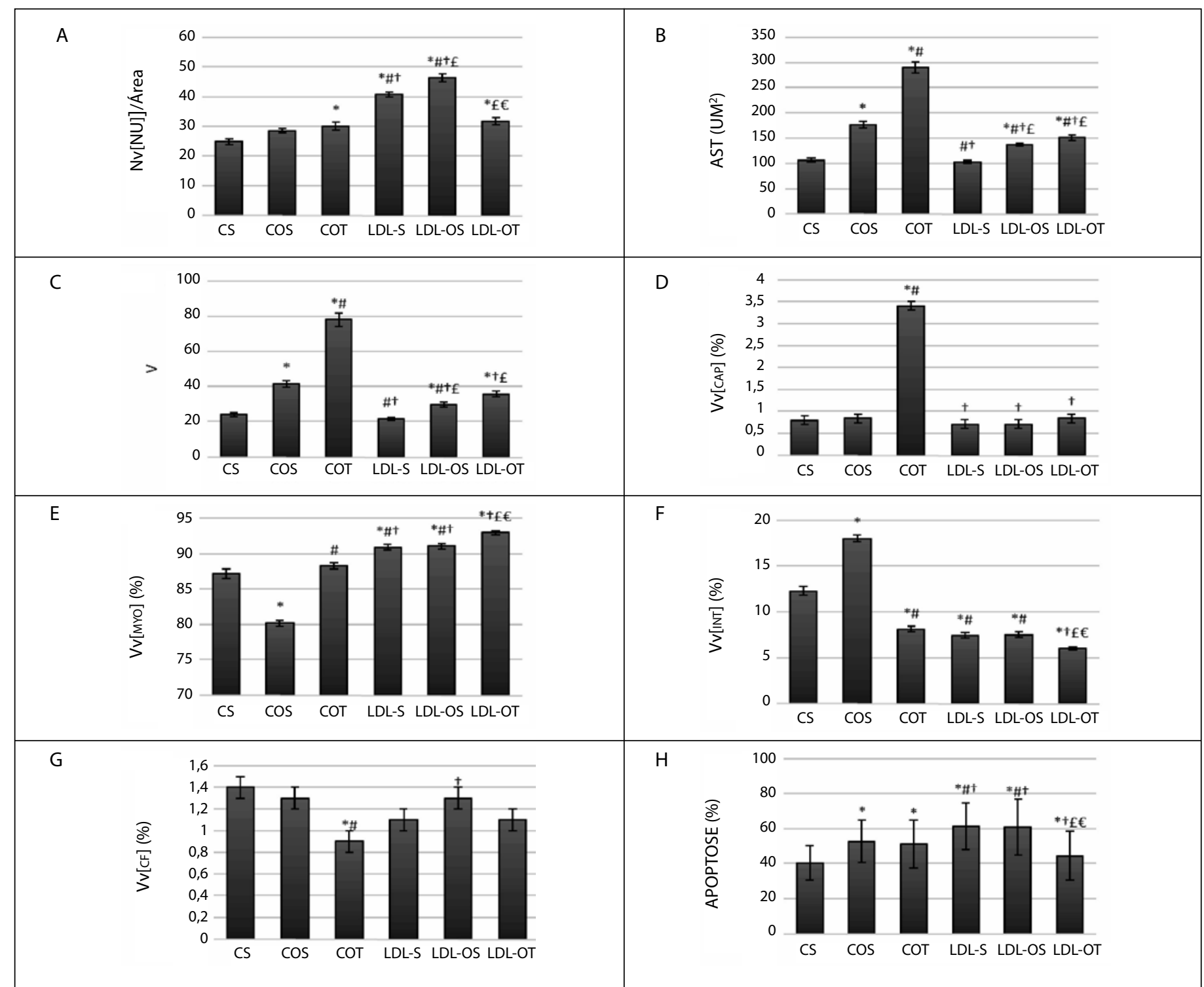

Figure 1. Effects of moderate exercise in the left ventricle in sedentary control (CS), sedentary ovariectomized control (COS), trained ovariectomized control (COT), LDL sedentary knockout (LDL-S), LDL knockout sedentary ovariectomized (LDL-OS ), LDL knockout ovariectomized trained (LDL-OT). (A) cores numerical density (Nv [nu); (B) the cross-sectional area of myocytes (AST); (C) Nuclear Medium Volume (V); (D) density volume of capillaries (Vv [cap]); (E) volume density of myocytes (Vv [myo]); (F) bulk density of the interstitium ( $V_{v}$ int [] ); (G) density volume and of the collagen fibers ( $V v$ [ms]) and (H) Apoptosis.

Mean \pm SEM. Values represent mean \pm SEM. ${ }^{*} p<0.05$ vs. CS; $\# p<0.05$ vs. WAISTBAND; $+p<0.05$ vs. COT; $£$ $p<0.05$ vs. LDLLS; $€ p<0.05$ vs. LDL-OS. 


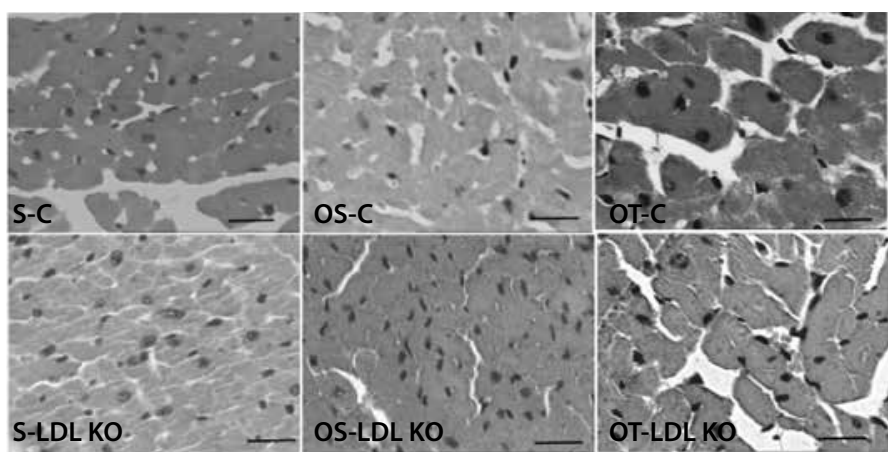

Figura 2. Photomicrographs of transverse histological sections of myocardium from animals in the studied groups (hematoxylin-eosin stain).

Notes: The characteristic homogenous structure seen in S-C. Myocyte hypertrophy evidenced by karyomegaly and hyperchromatic nuclei in OT-C and lower intensity in OT-LDL KO. Bar= 100 $\mu \mathrm{m}$
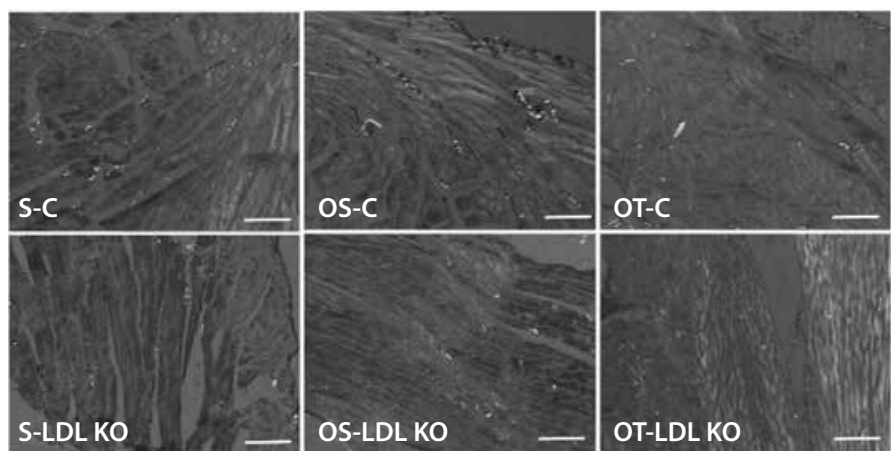

Figure 3. Photomicrographs of longitudinal sections of the myocardium stained by Picrossirius, viewed through polarized light. Bar $=100 \mu \mathrm{m}$.

Notes: Note the birefringent collagen fibers and their arrangement in the cardiac muscle tissue. Check the increase in collagen fibers in the OS-C and OS- LDL KO compared to S-C group.

Our data also showed that exercise training has beneficial effect on the heart tissue of ovariectomized and dyslipidemic females mice. We observed that the ovariectomy associated with exercise training in wild and / or dyslipidemic mice increased cross-sectional area of cardiomyocytes (AST) and the medium nuclear volume (V), suggesting myocyte hypertrophy. Similar results ${ }^{18,19}$ were observed in ovariectomized and trained rats, and in metabolic syndrome animals ${ }^{15}$ subject only to physical training. The hypertrophy of the heart muscle is an attempt to heart adaptation to the overload work ${ }^{11,20,21}$. Increased AST can, in a way, offer improved contractile function of the heart tissue and is an important mechanism in compensatory response to exercise. Morvan et al. ${ }^{15}$ in an experimental model of metabolic syndrome, suggested that the increase in AST may be due to local mechanical stimuli generated by the exercise itself associated with an inflammatory reaction caused by metabolic syndrome, which active growth factors, leading to hypertrophy of the fibers. As an example of this model, ovariectomy could be causing increased AST through a similar mechanism. In sedentary dyslipidemic animals increased AST was more discreet than the control group. This may be related to the high rate of apoptosis found in LDL-knockout group.

The maintenance or increase in myocyte volume density is considered fundamental to the normal heart function being related to changes in mechanical stress and associated with exercise ${ }^{22}$. In ovariectomy control animals (COS) decreases the $\mathrm{V} v$ [myo] and the exercise recovered these values, both control as dyslipidemic mice, corroborating the literature data demonstrating the role of physical activity in cardiac function ${ }^{22}$.

Additionally, the practice of aerobic training of moderate intensity (COT and LDL-OT) resulted in a significant increase in vascular network of the myocardium ( $\mathrm{V} v[\mathrm{ch}]$ ) and reduced interstitial density volume $(\mathrm{V}$ [int]) of the left ventricle of the animals when compared to control groups (CS, COS). The components of the cardiac interstitium have close relationship with the cell share being critical in transmitting extracellular information to the cardiac cells ${ }^{23}$. The decrease in interstitial space in the trained group may be explained by greater proportion occupied by vessels, along with increase in the number of myocytes per field and increase the area of myocytes.

LDL Knockout groups did not show significant differences among themselves and with the control animals (CS and COS) in Vv [cap] and Vv [int] suggesting that hyperlipidemia, even with physical exercise, not promoting growth of vascular network and predisposes an increase in the interstitial density volume. These adjustments improve heart function by increasing the nutritional content but can also be correlated with oxidative stress tissue as a result of angiogenesis and capillary density volume ${ }^{15}$.

Other studies have shown that aerobic exercise with or without the resistance training, improved myocardial vascularization and normalized the myocardial fibrosis in rats $24,12,15$. The high concentrations of PCR (C reactive protein) act directly on leukocyte recruitment and apoptosis in the vessel wall ${ }^{25,26}$. High PCR levels further inhibit nitric oxide synthesis in endothelial cells, facilitating apoptosis of these cells and by blocking angiogenesis ${ }^{27}$ contributed by high levels of apoptosis found in hyperlipemic groups.

The practice of aerobic training, COT group, resulted in decreased of collagen fibers volume density $(\mathrm{Vv}[\mathrm{fC}])$ in relation with the control CS and $\operatorname{COS}$ groups, correlating with the results obtained with $V_{v}$ [int]. The values of sedentary ovariectomized animals (COS) showed no significant difference in collagen fibers volume density $(\mathrm{Vv}[\mathrm{fc}])$ in relation with the control group (CS). These results suggest that the lack of production of hormones does not affect the volume of collagen fiber density, but the practice of moderate intensity aerobic training results in significant decreases. Animals LDL Knockout (LDL-S LDL-OS and LDL-OT) showed no significant difference between them, suggesting that the lack of hormones production associated with hyperlipidemia and practice of aerobic training of moderate intensity does not result in a change in density volume of collagen fibers, for animals of these groups. When comparing the animals from wild groups (CS and COS) with the animals LDL Knockout (LDL-S LDL-OS and LDL-T) was not observed significant differences between groups, suggesting that hyperlipidemia does not change the density profile volume of collagen fibers in the myocardium of these animals.

Studies show that in animals who exercise, the density of collagen fibers decreased probably due to remodeling in heart tissue in response to stimuli caused by mechanical or humoral agents released in response to exercise on the myocardium ${ }^{12,15}$. This remodeling of the tissue, can improve cardiac function by increasing ventricular compliance, increased coronary reserve potential of oxygen and nutrition to the myocytes, which reduces the risks of ventricular dysfunction ${ }^{24}$

The significative increased apoptosis rate in ovariectomized suggests that the reduction in hormone production during menopause can decrease the antioxidant capacity of the body, resulting in increased cell death rate. In the control group (COT), the training has not been able to reverse the effects of ovariectomy (COS) once the apoptosis rate was similar in both groups. Thus, there was no direct relationship between physical activity and increased apoptosis, unlike studies in various cell lines indicating that oxidative stress caused by physical activities metabolism is associated with apoptosis ${ }^{28}$. Among the sedentary animals and ovariectomized of LDL knockout groups (LDL-S and LDL-OS) apoptosis rate was even higher when compared to the animals of the control group, suggesting that ovariectomy is not the main factor for induction of apoptosis, and the dyslipidemia an important role in increased cell death. Similarly, Qin et a ${ }^{29}$ observed that dyslipidemia increases the rate of apoptosis in the endothelium of arteries and heart cells relating this fact to the release of reactive oxygen species released by the oxidation 
of $L D L$ in the tissues. Unlike controls, training reversed cell death in LDL-OT group significantly, approaching its rate than sedentary control group (CS). Kaidah et al..$^{30}$ also verified this action of physical activity in the hippocampus of ovariectomized rats trained. Comparing the wild groups and knockout, it can infer that the effect of physical activity on cell death may depend on the oxidative stress of the tissue level. That would explain the differentiated behavior training in both groups. However, larger studies are needed to demonstrate this relationship.

In general, it became clear in this study that for most of the parameters evaluated responses to training, have always been more evident in the trained wild group (COT). Even when the knockout group had similar response, she was always less pronounced. This shows that in animals dyslipidemic signaling pathways are damaged in any way, leading to cell response is always smaller.

\section{CONCLUSION}

The data of this study indicate that the aerobic training influenced beneficially histophysiology the heart and ovariectomized female Hyperlipemic mice. The trained ovarectomized group (COT) presented myocyte hypertrophy, increased myocyte density, increase in density capillaries, reduction in volume density and decrease interstitial volume density of collagen fibers. The LDL-OT group achieved a reduction in the number density of nuclei in the cross section of myocytes, myocyte hypertrophy, increased myocyte density and a reduction in the interstitial volume density, and significant reduction in the process of apoptosis in cardiomyocytes.

All authors declare no potential conflict of interest related to this article.

AUTHORS' CONTRIBUTIONS: Each author made significant individual contributions to this manuscript. LB (0000-0003-2087-4891)*: LBMM (0000-0002-9456-192X)*: CGC (0000-0002-9175-7695)*: and FLAF (0000-0003-1223-1589)*: were the main contributors in drafting the manuscript. LB and LBMM performed the experiment and collected the data. LB, LBMM, CGC, FLAF and MRM (0000-0002-5955-1056)*: evaluated the data for the statistical analysis. MLJM (0000-0003-14388205)*: and other authors carried out the bibliographic research, reviewed the manuscript and contributed to the intellectual concept of the study. *ORCID (Open Researcher and Contributor ID).

\section{REFERENCES}

1. Zanesco A, Antunes E. Effects of exercise training on the cardiovascular system: pharmacological approaches. Pharmacol Ther. 2007;114(3):307-17

2. Coylewright M, Reckelhoff JF, Ouyang P. Menopause and hypertension: an age-old debate. Hypertension. 2008;51(4):952-9.

3. Humphreys V, Martin RM, Ratcliffe B, Duthie S, Wood S, Gunnell D, et al. Age-related increases in DNA repair and antioxidant protection: a comparison of the Boyd Orr Cohort of elderly subjects with a younger population sample. Age Ageing. 2007;36(5):521-6.

4. Lee HC, Wei YH. Oxidative stress, mitochondrial DNA mutation, and apoptosis in aging. Exp Biol Med (Maywood). 2007;232(5):592-606

5. David OJ, Ocwieja M, Meiser K, Emotte C, Jakab A, Wemer J, et al. Pharmacokinetics of fingolimod (FTY720) and a combined oral contraceptive coadministered in healthy women: drug-drug interaction study results. Int J Clin Pharmacol Ther. 2012;50(8):540-4

6. Gobal FA, Mehta JL. Management of dyslipidemia in the elderly population. Ther Adv Cardiovasc Dis. 2010;4(6):375-83

7. Ammar T. Effects of aerobic exercise on blood pressure and lipids in overweight hypertensive postmenopausal women. J Exerc Rehabil. 2015;11(3):145-50.

8. Perrella J, Berco M, Cecutti A, Gerulath A, Bhavnani BR. Potential role of the interaction between equine estrogens, low-density lipoprotein ( $L D L$ ) and high-density lipoprotein (HDL) in the prevention of coronary heart and neurodegenerative diseases in postmenopausal women. Lipids Health Dis. 2003;2:4.

9. Irigoyen MC, Paulini J, Flores $L$, Flues $K$, Bertagnolli M, Moreira ED, et al. Exercise training improves baroreflex sensitivity associated with oxidative stress reduction in ovariectomized rats. Hypertension. 2005;46(4):998-1003.

10. Valença CN, Nascimento Filho JM, Germano RM. Mulher no climatério: reflexões sobre desejo sexual, beleza e feminilidade. Saude Soc. 2010;19(2):273-85.

11. Mandarim-de-Lacerda CA, Pessanha MG. Stereology of the myocardium in embryos, fetuses and neonates of the rat. Acta Anat (Basel). 1995;154(4):261-6.

12. Maifrino LB, Araújo RC, Faccini CC, Liberti EA, Gama EF, Ribeiro AA, et al. Effect of exercise training on aging-induced changes in rat papillary muscle. Arq Bras Cardiol. 2009;92(5):356-60,373-7,387-92.

13. Souza SB, Flues K, Paulini J, Mostarda C, Rodrigues B, Souza LE, et al. Role of exercise training in cardiovascular autonomic dysfunction and mortality in diabetic ovariectomized rats. Hypertension. 2007;50(4):786-91.

14. Silva AS, Zanesco A. Exercício físico, receptores $\beta$-adrenérgicos e resposta vascular. J Vasc Bras. 2010;9(2):47-56.

15. Morvan E, Lima NE, Machi JF, Mostarda C, De Angelis K, Irigoyen MC, et al. Metabolic, hemodynamic and structural adjustments to low intensity exercise training in a metabolic syndrome model. Cardiovasc Diabetol. 2013;12:89.
16. Marchon C, de Marco Ornelas E, da Silva Viegas KA, Lacchini S, de Souza RR, Fonseca FL, et al. Effects of moderate exercise on the biochemical, physiological, morphological and functional parameters of the aorta in the presence of estrogen deprivation and dyslipidemia: an experimental model. Cell Physio Biochem. 2015;35(1):397-405

17. Choi KM, Kwon YY, Lee CK Characterization of global gene expression during assurance of lifespan extension by caloric restriction in budding yeast. Exp Gerontol. 2013;48(12):1455-68

18. Vieira, FV Efeitos da ooforectomia e exercício aeróbio sobre o músculo papilar do ventrículo esquerdo de ratas wistar: análise morfométrica e estereológica. Dissertação do programa de pós-graduação em Educação Física da Universidade São Judas Tadeu. 2009.

19. Diffee GM, Nagle DF. Regional differences in effect of exercise training on contractile and bioquemical properties of rat cardiac myocytes. J. Appl. Physiol (1985). 2003;95(1):35-42.

20. Cardoso JA, Toscano AE, Tashiro T, Carvalho CAF, Moraes SRA. Morfometria do miocárdio humano em indivíduos senis. Arq Bras Cardiol. 2006;86(5):374-7.

21. Natali AJ. Efeitos do exercício crônico sobre os miócitos cardíacos: uma revisão das adaptações mecânicas. Rev Bras Ci e Mov. 2004:12(1)91-6.

22. Moore RL, Korzick DH. Cellular adaptations of the myocardium to chronic exercise. Prog Cardiovasc Dis. 1995:37(6):371-96

23. Simpson DG, Carver W, Borg TK, Terracio L. Role of mechanical stimulation in the establishment and maintenance of muscle cell differentiation. Int Rev Cytol. 1994;150:69-94.

24. Matsubara LS, Narikawa S, Ferreira AL, Paiva SA, Zornoff LM, Matsubara BB. Myocardial remodeling in chronic pressure or volume overload in the rat heart. Arq Bras Cardiol. 2006;86(2):126-30.

25. Verma S, Szmitko PE, Yeh ET. C-reactive protein: structure affects function. Circulation. 2004;109(16):1914-7.

26. Kubo T, Matsuo Y, Hayashi Y, Yamano T, Tanimoto T, Ino Y, et al. High-sensitivity C-reactive protein and plaque composition in patients with stable angina pectoris: a virtual histology intravascular ultrasound study. Coron Artery Dis. 2009;20(8):531-5.

27. Verma S, Wang CH, Li SH, Dumont AS, Fedak PW, Badiwala MV, et al. A self-fulfilling prophecy: C-reactive protein attenuates nitric oxide production and inhibits angiogenesis. Circulation. 2002:106(8):913-9

28. Goon, JA, Noor Aini AH, Musalmah M, Yasmin Anum MY, Wan Njah WZ." "Long term Tai Chi exercise reduced DNA damage and increased lymphocyte apoptosis and proliferation in older adults. Med J Malaysia. 2008;63(4):319-324.

29. Qin B, Cao Y, Yang H, Xiao B, Lu Z. MicroRNA-221/222 regulate ox-LDL-induced endothelial apoptosis via Ets-1/p21 inhibition. Mol Cell Biochem. 2015;405(1-2):115-24

30. Kaidah S, Soejono SK, Partadiredja G. Exercise improves hippocampal estrogen and spatial memory of ovariectomized rats. Bratisl Lek Listy. 2016;117(2):94-9 